\title{
Characteristics of a 28-kDa Collagenous Protein Extracted with Guanidine from EDTA-Demineralized Rabbit Alveolar Bone
}

\author{
Masao MAENO ${ }^{1}$, Eiji OIKAWA ${ }^{1}$, Minoru TAGUCHI ${ }^{1}$, Naoto SUZUKI ${ }^{1}$, \\ Yukinobu SHIRAISHI ${ }^{1}$, Akihiko HAYASHI ${ }^{1}$, Noriko YAHAGI $^{2}$, \\ Ichiro KATAYAMA ${ }^{3}$ and Kichibee OTSUKA ${ }^{1}$
}

(Received 28 June and accepted 2 September 1993)

Key words: alveolar bone, collagen, $\mathrm{pN}$-propeptide, matrix protein

\begin{abstract}
Bone proteins in alveolar bone of mandibles from young adult rabbits (3-month-old) were extracted with $4.0 \mathrm{M}$ guanidine hydrochloride $(\mathrm{GuHCl})$, followed by $0.5 \mathrm{M}$ ethylenediaminetetraacetate, and again with $4.0 \mathrm{M} \mathrm{GuHCl}$ (G2-ext). The proteins in the G2-ext were fractionated on a gel-filtration column, followed by an anion-exchange column in the presence of $7.0 \mathrm{M}$ urea. A $28-\mathrm{kDa}$ protein was isolated from the G2-ext. The purified 28-kDa protein showed intense staining with silver on SDS-PAGE slab-gel under reducing conditions. This protein was digested with bacterial collagenase, and a 19-kDa fragment appeared on the gel. However, the protein was not susceptible to reduction with cyanogen bromide. The protein did not bind to hydroxyapatite crystals in the presence of $7.0 \mathrm{M}$ urea, and also did not bind to some lectins. On SDS-PAGE under non-reducing conditions, the protein migrated as two bands; a new band appeared at approximately the $85-\mathrm{kDa}$ region in addition to the original $28-\mathrm{kDa}$ band. The amino acid compositions of the protein were similar to those of the $\alpha 1$-pN-propeptide of type I procollagen obtained from other tissues.
\end{abstract}

\section{Introduction}

A small collagenous protein present in demineralized extracts of fetal bovine bone using guanidine hydrochloride $(\mathrm{GuHCl})$ solution was first reported by Termine et al. ${ }^{[1]}$ Subsequently, it was characterized as a phosphorylated form of the $\alpha 1$-pN-propeptide of type I procollagen [ $\alpha$ 1 (I)pN-propeptide] from fetal human bone, fetal bovine bone ${ }^{[2]}$, and adult bovine bone ${ }^{[3]}$. Using a selective extraction procedure, however, two forms of propeptides with different affinities for hydroxyapatite were isolated from demineralized extracts of fetal porcine bone, and a third form was identified by subsequent extraction of the demineralized matrix with $4.0 \mathrm{M} \mathrm{GuHCl}^{[4,5]}$. In addition, two other small collagenous proteins with affinity for hydroxyapatite have also been identified in fetal porcine bone using a monoclonal antibody ${ }^{[5,6]}$.

We have recently reported the presence of a $28-\mathrm{kDa}$ protein in the mineralized matrix of alveolar bone from young adult rabbits extracted with $0.5 \mathrm{M}$ ethylenediaminetetraacetate (EDTA), which was identified as the $\alpha 1$ (I)pN-propeptide, and also demonstrated the production

前野正夫 ${ }^{1}$, 及川栄二 ${ }^{1}$, 田口稔 ${ }^{1}$, 鈴木直人 $^{1}$, 白石行延 $^{1}$, 林昭彦 $^{1}$, 矢作典子 $^{2}$, 片山一郎 $^{3}$, 大塚吉兵衛 $^{1}$

1 Department of Biochemistry, Nihon University School of Dentistry, 1-8-13, Kanda-Surugadai, Chiyoda-ku, Tokyo 101, Japan

2 Division of Anatomy, Nihon University School of Dentistry, 1-8-13, Kanda-Surugadai, Chiyoda-ku, Tokyo 101, Japan

3 Division of Clinical Research, Dental Research Center, Nihon University School of Dentistry, 1-8-13, KandaSurugadai, Chiyoda-ku, Tokyo 101, Japan

To whom all correspondence should be addressed: Dr. Masao MAENO, Department of Biochemistry, Nihon University School of Dentistry, 1-8-13, Kanda-Surugadai, Chiyoda-ku, Tokyo 101, JAPAN 
of this protein by rabbit alveolar bone-derived cells ${ }^{[7]}$. However, little has been reported regarding the presence of the $\alpha 1(\mathrm{I}) \mathrm{pN}$-propeptide in a subsequent extract of the demineralized bone matrix of rabbit alveolar bone obtained with 4.0 M GuHCl (G2-ext).

In this study, we purified a significant amount of the $28-\mathrm{kDa}$ collagenous protein in the $\mathrm{G} 2$-ext of rabbit alveolar bone, and identified it as the $\alpha 1(\mathrm{I}) \mathrm{pN}$-propeptide from its characteristics.

\section{Materials and Methods}

\section{Tissue Preparation and Protein Extraction}

Fresh alveolar bone fragments were obtained from mandibles of young adult rabbits (3 months old). Attached soft connective tissues including the periosteum were removed carefully from the mandibles, and a portion of spongy bone was also removed to avoid contamination with bone marrow and blood components. The bone fragments were crushed to a particle size of less than $2 \mathrm{~mm}^{3}$ in liquid nitrogen. The extraction of bone proteins was performed using a modified method ${ }^{[4,7-14]}$, which was originally described by TERMINE et al. ${ }^{[1]}$ Briefly, after the bone particles had been thoroughly washed with phosphate-buffered saline (PBS, Nissui Pharmaceutical Co., Tokyo, Japan), components of the non-mineralized portion were extracted with $4.0 \mathrm{M}$ $\mathrm{GuHCl}$ (Wako Pure Chemical Industries, Tokyo, Japan) solution, buffered at pH 7.4 with 50 $\mathrm{mM}$ Tris-HCl. The bone particles were again washed extensively with PBS, and the mineralbinding proteins were extracted from the mineralized matrix with $0.5 \mathrm{M}$ EDTA (Wako) solution, buffered at pH 7.4 with $50 \mathrm{mM}$ Tris-HCl. The EDTA-demineralized bone matrix of the particles was rinsed with PBS, and then the matrix-binding proteins were extracted with $4.0 \mathrm{M}$ $\mathrm{GuHCl}$ solution as described above $\mathrm{e}^{[4,7-14]}$. The volume ratio of the extractant was $200 \mathrm{ml}$ per $1 \mathrm{~g}$ tissue for each extraction, and all the extraction steps subsequent to tissue preparation were performed at $4^{\circ} \mathrm{C}$. All the solutions used for the extraction contained protease inhibitors [1.0 mM phenylmethylsulfonyl fluoride (Sigma Chemical Co., St. Louis, Mo., USA), $5.0 \mathrm{mM}$ benzamidine hydrochloride (Tokyo Kasei Kogyo Co., Tokyo, Japan), $10 \mathrm{mM} \varepsilon$-amino caproic acid (Wako) and 5.0 mM N-ethylmaleimide (NEM, Sigma)].

\section{SDS-Polyacrylamide Gel Electrophoresis}

SDS-polyacrylamide gel electrophoresis (SDS-PAGE) was carried out using mini slab-gels (15\% linear or 5 20\% gradient gels, $63 \times 85 \times 0.75 \mathrm{~mm}$, Bio-Rad Laboratories, Richmond, CA, USA) to analyze the extracted proteins.

The Tris-glycine buffer system described by LAEMmLi[ ${ }^{[15]}$ was utilized for SDS-PAGE. Samples were dissolved in $10 \mu \mathrm{l}$ of sample buffer containing $1 \%$ SDS, $2.0 \mathrm{M}$ urea, and bromophenol blue. For electrophoresis under reducing conditions, $1.5 \%(\mathrm{w} / \mathrm{v})$ dithiothreitol was added to the sample solutions prior to heating at $90^{\circ} \mathrm{C}$ for $5 \mathrm{~min}$. The electrophoresis was performed at $150 \mathrm{~V}$ for $1 \mathrm{~h}$ using the mini slab-gel, and the gel was stained with either $0.2 \%(\mathrm{w} / \mathrm{v})$ silver nitrate (Wako) as described by Merril et al. ${ }^{[16]}$, or with $0.025 \%(\mathrm{w} / \mathrm{v})$ Stains-all (Sigma) as described by CAMPBELl et al. ${ }^{[17]}$

\section{Purification of 28-kDa Collagenous Bone Protein}

Proteins extracted with the second $\mathrm{GuHCl}$ solution (G2-ext) were concentrated up to 400-fold by ultrafiltration with a Diaflo apparatus using a YM-10 Diaflo membrane (Amicon Co., Lexington, KY, USA), and then dialyzed against $0.1 \mathrm{M}$ ammonium bicarbonate containing $0.005 \%$ Brij 35 (Sigma). The concentrated G2-ext was then freeze-dried and used for further purification.

\section{1) Superdex 200 Column Chromatography}

Approximately $45 \mathrm{mg}$ of the freeze-dried G2-ext was dissolved in $2.0 \mathrm{ml}$ of $7.0 \mathrm{M}$ urea- $0.2 \mathrm{M}$ $\mathrm{NaCl}$ in $50 \mathrm{mM}$ Tris- $\mathrm{HCl}$ buffer ( $\mathrm{pH} 7.4$ ), and clarified with a column guard (mesh size: $0.45 \mu \mathrm{m}$, 
Millipore Co., Bedford, Mass., USA). The filtered solution was applied to Superdex 200 column (HiLoad, $2.6 \times 90 \mathrm{~cm}$, Pharmacia Fine Chemicals, Uppsala, Sweden) and eluted with the above buffer at a flow rate of $1.0 \mathrm{ml} / \mathrm{min}$. The eluate was collected in $2.0-\mathrm{ml}$ fractions, and the protein concentration was monitored by absorbance at $280 \mathrm{~nm}$. Proteins eluted in the 20 35-kDa region were pooled and concentrated by ultrafiltration as described above. The concentrated protein solution was desalted by Sephadex G-25 column (PD-10, Pharmacia) in $0.5 \mathrm{M}$ acetic acid, and freeze-dried.

\section{2) Mono $Q$ Column Chromatography}

The above freeze-dried material was applied to Mono $\mathrm{Q}$ resin-packed analytical column $(0.5 \times 5.5 \mathrm{~cm}$, Pharmacia) equilibrated with $50 \mathrm{mM}$ Tris- $\mathrm{HCl}$ buffer $(\mathrm{pH} 7.4)$ containing $7.0 \mathrm{M}$ urea. The proteins were eluted with a linear gradient of $0 \sim 1.0 \mathrm{M} \mathrm{NaCl}$ at a flow rate of $1.0 \mathrm{ml}$ / min by HPLC (Ultrochrom GTi, LKB-Produkter AB, Bromma, Sweden) system. The eluate was collected in $1.0-\mathrm{ml}$ fractions, and the protein concentration was monitored by absorbance at 230 $\mathrm{nm}$.

The purity of the $28-\mathrm{kDa}$ protein in the fractions was assessed by SDS-PAGE with a $15 \%$ mini slab-gel using Stains-all and silver staining to visualize the proteins. Fractions containing the proteins of interest were desalted by chromatography on PD-10 column in $0.5 \mathrm{M}$ acetic acid.

\section{Characterization of the Purified 28-kDa Proteins}

\section{1) Digestion with Bacterial Collagenase}

The purified $28-\mathrm{kDa}$ protein was incubated with highly purified bacterial collagenase (15 unit/5.58 mg, Boehringer Mannheim, Mannheim, Germany) using a $1: 10$ enzyme to protein ratio. The digestion was performed in $20 \mu \mathrm{l}$ of $50 \mathrm{mM}$ Tris- $\mathrm{HCl}$ buffer supplemented with $5 \mathrm{mM}$ $\mathrm{CaCl}_{2}$ and $5 \mathrm{mM} \mathrm{NEM} \mathrm{(pH} \mathrm{7.4)} \mathrm{for} 30 \mathrm{~min}$ at $37^{\circ} \mathrm{C}$.

2) Cleavage with Cyanogen Bromide

The protein was dissolved in $100 \mu 1$ of $70 \%$ formic acid, flushing with nitrogen gas for $1 \mathrm{~min}$, and approximately $1 \mathrm{mg}$ of cyanogen bromide $(\mathrm{CNBr}$, Wako) was added to approximately $1 \mu \mathrm{g}$ of protein. The solution was briefly flushed again with nitrogen, and incubated for $4 \mathrm{~h}$ at $27^{\circ} \mathrm{C}$. This solution was then diluted 40 -fold with water, and freeze-dried.

\section{3) Hydroxyapatite Column Chromatography}

The purified protein was applied to a hydroxyapatite column made by packing hydroxyapatite (HP20, Asahi Kagaku Kogyo Co., Tokyo, Japan) into an HR 10/10 column $(1 \times 10 \mathrm{~cm}$, Pharmacia). The column was equilibrated with a starting buffer (50 mM Tris-HCl buffer, $\mathrm{pH} 7.4$, containing $10 \mathrm{mM}$ phosphate and $7.0 \mathrm{M}$ urea). After applying the material at a flow rate of 0 . $2 \mathrm{ml} / \mathrm{min}$, the column was washed with $15 \mathrm{ml}$ of the starting buffer at a flow rate of $0.5 \mathrm{ml} / \mathrm{min}$, and the protein was eluted with a linear gradient of $10 \sim 500 \mathrm{mM} \mathrm{Na}_{2} \mathrm{HPO}_{4}$. The eluate was fractionated into $1.0-\mathrm{ml}$ aliquots, and the protein concentration was monitored by absorbance at $230 \mathrm{~nm}$. Some fractions containing high protein concentrations were collected, and SDSPAGE was performed to detect the $28-\mathrm{kDa}$ protein.

4) Western Blotting

The binding abilities of several biotin-conjugated lectins to $1 \mu \mathrm{g}$ of the $28-\mathrm{kDa}$ protein were determined using a lectin sensor kit (Seikagaku Co., Tokyo) including the following lectins: Aleuria aurantia (AAA), Sambucus sieboldiana (SSA), Ricinus communis (RCA 120) and Datura stramonium (DSA). These lectins, AAA, SSA, RCA 120, and DSA, recognize Fuc $\alpha 1^{[18]}$, Sia $\alpha 2-6 \mathrm{Gal}^{[19]}, \mathrm{Gal}^{[20]}$, and $\mathrm{Gal} \beta 1-4 \mathrm{GlcNAc}^{[21]}$ of carbohydrate chains in glycoconjugates, respectively.

Immunotransfer analysis was performed on a Multiphor II Novo Blot system (LKB, Uppsala, Sweden) using a polyvinylidene difluoride (PVDF) microporous membrane (Immobilon PVDF; Millipore) with a continuous buffer system composed of $39 \mathrm{mM}$ glycine, $48 \mathrm{mM}$ Tris, $0.0375 \%$ SDS and $20 \%(\mathrm{v} / \mathrm{v})$ methanol. The electrophoresis was carried out at a constant 
current of $1.0 \mathrm{~mA} / \mathrm{cm}^{2}$ of gel for $90 \mathrm{~min}$. After the transfer, the excess protein-binding sites on the membrane were blocked with $0.01 \mathrm{M}$ Tris- $\mathrm{HCl}$ buffer ( $\mathrm{pH} 7.4$ ) containing $0.45 \mathrm{M} \mathrm{NaCl}$ and $0.05 \%$ Tween-20 (blocking buffer) at $4^{\circ} \mathrm{C}$ for $18 \mathrm{~h}$. The sheets were incubated at $22^{\circ} \mathrm{C}$ for 60 min with each biotin-conjugated lectins diluted in $4 \mu \mathrm{g} / \mathrm{ml}$ with the blocking buffer. The sheets were washed three times with the blocking buffer, and then incubated at $22^{\circ} \mathrm{C}$ for 15 min with HRP-conjugated avidin diluted to $1 \mu \mathrm{l} / \mathrm{ml}$ with the blocking buffer. The sheets were again washed three times with the blocking buffer, and then incubated with PBS containing $0.06 \%$ 4-chloro-1-naphthol and $0.04 \% \mathrm{H}_{2} \mathrm{O}_{2}$.

5) Amino Acid Analysis

The purified 28-kDa protein was hydrolyzed in $6.0 \mathrm{M} \mathrm{HCl}$ at $110^{\circ} \mathrm{C}$ for $22 \mathrm{~h}$ in vials sealed under nitrogen. The amino acid composition was determined using a Shimadzu amino acid analyzer (column; Shim-pak ISC-07/S1504 Na, Shimadzu Co., Kyoto, Japan).

\section{Results}

Proteins in rabbit alveolar bone were sequentially extracted with $4.0 \mathrm{M} \mathrm{GuHCl}$, then with $0.5 \mathrm{M}$ EDTA, followed by $4.0 \mathrm{M} \mathrm{GuHCl}$ solution; the extracts obtained were termed G1-ext, E-ext and G2-ext, respectively. The proteins in each extract were analyzed by SDS-PAGE using silver (Fig 1), and Stains-all staining (data not shown). Among the three extracts, the G2-ext contained a limited number of clearly resolved proteins corresponding to molecular masses of $120 \sim 200-\mathrm{kDa}$ and $25 \sim 70-\mathrm{kDa}$. A protein band in the 30-kDa region, which stained with silver and also stained light blue with Stains-all, was present in the G2-ext (arrowhead in Fig. 1), corresponding to a protein in the E-ext as described by OHMORI et al. ${ }^{[10]}$ and MAENo et al. ${ }^{[7]}$ From its staining characteristics, this protein appeared to be the $28-\mathrm{kDa}$ collagenous protein of rabbit alveolar bone. Therefore, we purified the protein utilizing sequential chromatography on Superdex 200 and Mono Q column under denaturing conditions.

The proteins in the G2-ext were first fractionated using Superdex 200 column in the presence of 7.0 M urea. The elution profile of the proteins is shown in Fig. 2. Protein bands in every third fraction of the run were analyzed by SDS-PAGE to determine the elution position of 20 $\sim 35-\mathrm{kDa}$ proteins, and aliquots of the eluate in fraction numbers 89 to 92 were collected (bar in Fig. 2). The pooled eluate was freeze-dried, and then applied to Mono Q column in the presence of 7.0 M urea as described in Materials and Methods. The elution was performed using a linear gradient of $\mathrm{NaCl}(0 \sim 1.0 \mathrm{M})$. The proteins were separated into six peaks; one peak was in the flow-through fraction, and five peaks were in the bound fractions of the column as shown in Fig. 3. Aliquots from each peak were analyzed by SDS-PAGE, and the 28-kDa protein was identified mainly in the highest peak of the bound fractions, fraction numbers 14 and 15 (bar in Fig. 3). The final purification of the $28-\mathrm{kDa}$ protein was carried out by re-chromatography on Mono Q column in the presence of $7.0 \mathrm{M}$ urea, and the protein was eluted in fraction number 23 (bar in Fig. 4). The protein bands in the fractions were determined by SDS-PAGE. The $28-\mathrm{kDa}$ protein was purified as a single band in fraction number 23, as shown in lane 1 of Fig. 5 .

The purified 28-kDa protein (G2-28K) was stained intensely with silver (Fig. 5, lane 1), and also stained light blue with Stains-all (Fig. 5, lanes 4 and 5) on the SDS-PAGE slab-gel under reducing conditions. When SDS-PAGE was performed without urea and reduction, an additional band, which migrated at approximately $85 \mathrm{kDa}$, appeared in the G2-28K fraction (Fig. 5, lane 6).

When the G2-28K was treated with bacterial collagenase, the molecular weight decreased to $19 \mathrm{kDa}$ (Fig. 5, lane 2). The collagenase-resistant 19-kDa fragment was stained light blue with Stains-all, similar to the original 28-kDa protein (Fig. 5, lane 5).

After incubation with $\mathrm{CNBr}$ under nitrogen, the mobility of G2-28K was unchanged, indicating resistance to $\mathrm{CNBr}$ cleavage (Fig. 5, lane 3).

When the G2-28K was chromatographed on a hydroxyapatite column with a linear gradient 


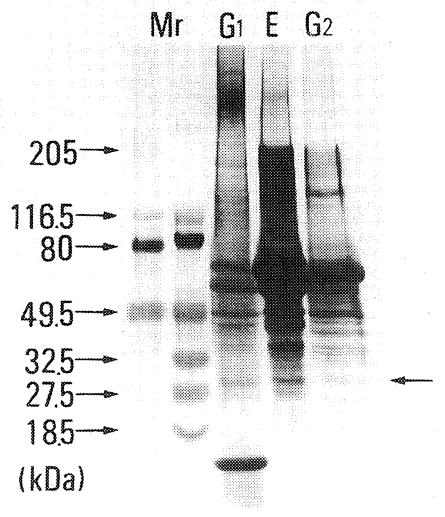

Fig. I SDS-PAGE analysis of proteins in G1-, $\mathrm{E}$-, and G2-ext from alveolar bone of young adult rabbit

SDS-PAGE was performed using a 5 $20 \%$ gradient cross-linked gel under reducing conditions, and then stained with silver. $\mathrm{Mr}$ values indicate molecular weight marker proteins. Gl, proteins extracted with $4.0 \mathrm{M} \mathrm{GuHCl}$ (G1-ext); E, proteins extracted with $0.5 \mathrm{M}$ EDTA (E-ext); G2, proteins re-extracted with 4.0 M GuHCl (G2-ext). Arrowhead indicates a $28-\mathrm{kDa}$ protein in G2-ext.

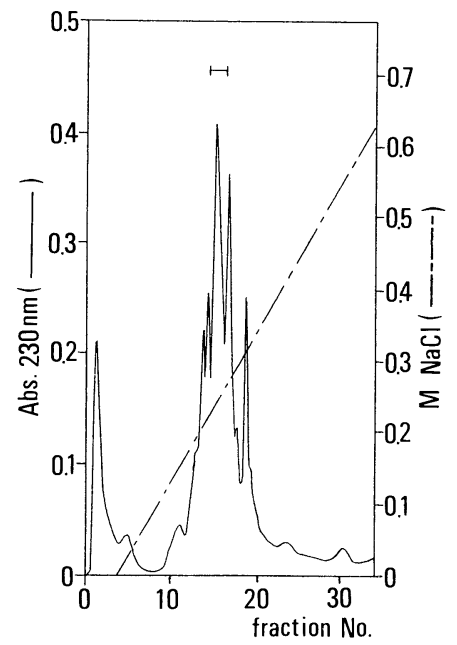

Fig. 3 Mono Q column chromatography

The freeze-dried material pooled from the Superdex 200 run was dissolved in $1.0 \mathrm{ml}$ of $50 \mathrm{mM}$ Tris- $\mathrm{HCl}$ buffer ( $\mathrm{pH} 7.4)$ containing $7.0 \mathrm{M}$ urea, and applied to Mono $Q$ column $(0.5 \times 5.5 \mathrm{~cm})$. The proteins were eluted with a linear gradient of $\mathrm{NaCl}$, and $1.0-\mathrm{ml}$ fractions were collected; the column was run at $1.0 \mathrm{ml} /$ min. Protein concentrations were monitored by absorbance at $230 \mathrm{~nm}$. Fractions containing the $28-\mathrm{kDa}$ protein were pooled (bar), and then freeze-dried.

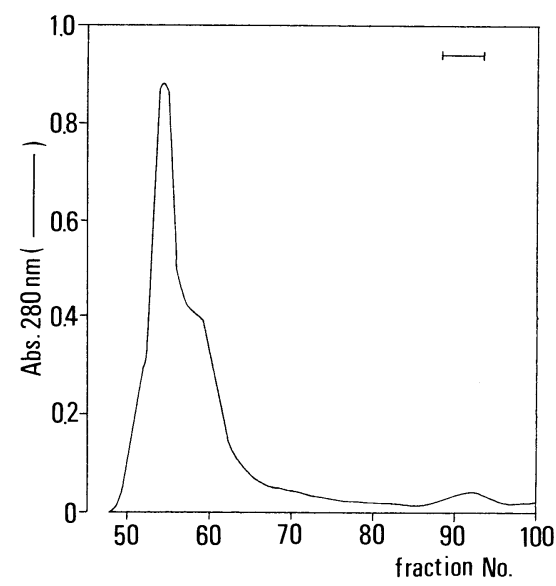

Fig. 2 Superdex 200 column chromatography of the G2-ext

Approximately $45 \mathrm{mg}$ of the G2-ext was dissolved in $2.0 \mathrm{ml}$ of $50 \mathrm{mM}$ Tris- $\mathrm{HCl}$ buffer ( $\mathrm{pH}$ 7.4) containing $7.0 \mathrm{M}$ urea and $0.2 \mathrm{M} \mathrm{NaCl}$ solution. The solution was applied to Superdex 200 column $(2.6 \times 90 \mathrm{~cm})$, run at $1.0 \mathrm{ml} / \mathrm{min}$, and 2.0-ml fractions were collected. Protein concentrations were monitored by absorbance at $280 \mathrm{~nm}$. Fractions containing 20-35-kDa proteins were pooled (bar), and then freeze-dried.

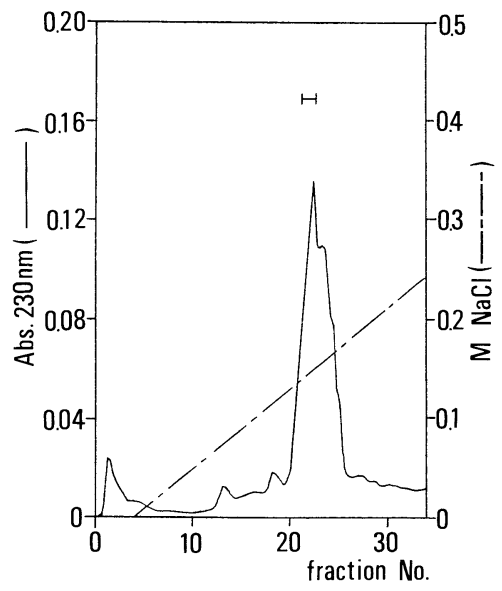

Fig. 4 Mono Q column re-chromatography The freeze-dried material pooled from the first Mono $Q$ run was again applied to Mono Q column. Fractions containing the $28-\mathrm{kDa}$ protein were pooled (bar), and then freeze-dried to determine some of their characteristics. 


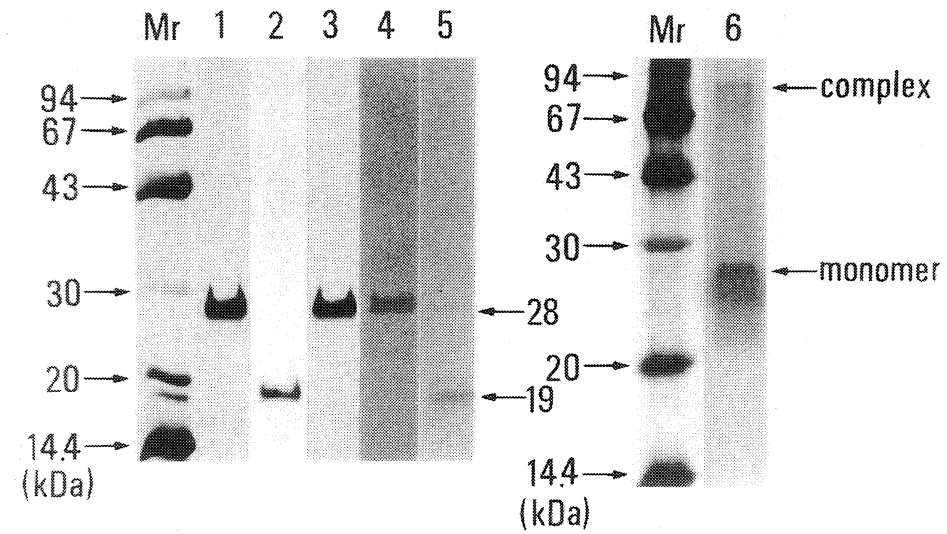

Fig. 5 Characterization of the purified 28-kDa protein The purified $28-\mathrm{kDa}$ protein $(\mathrm{G} 2-28 \mathrm{~K})$ was applied to a linear gel (15\%) on the minislab system under reducing (lanes 1 to 5) or non-reducing (lane 6) conditions. After SDS-PAGE, the gel was stained with silver (lanes 1 to 3 and 6) or Stains-all (lanes 4 and 5). Mr indicates molecular weight standards. G2-28K (lane 1) was digested with bacterial collagenase (lanes 2 and 5), generating a 19-kDa collagenase-resistant fragment. Lane 3 shows G2-28K, which was resistant to $\mathrm{CNBr}$ cleavage. Lanes 4 and 5 show light blue staining with Stains-all for both the $28-\mathrm{kDa}$ protein and the $19-\mathrm{kDa}$ fragment, respectively. Lane 6 shows the mobility of G2-28K under non-reducing conditions without urea.

of $\mathrm{Na}_{2} \mathrm{HPO}_{4}(10 \sim 500 \mathrm{mM})$, the protein was eluted in the flow-through fraction (data not shown).

Lectin-binding assays carried out by Western blotting showed that AAA, SSA, RCA 120 and DSA did not bind to the G2-28K (data not shown).

The amino acid composition of G2-28K is shown in Table 1 . The G2-28K possessed a high

Table 1 Amino acid composition of G2-28K

\begin{tabular}{lcccc}
\hline \hline & \multicolumn{4}{c}{ Composition (residues/1000 residues) } \\
\cline { 2 - 5 } Amino acid & $\begin{array}{l}\text { Young adult-rabbit } \\
\text { alveolar bone } \\
\text { G2-28K }\end{array}$ & $\begin{array}{l}\text { Young adult-rabbit } \\
\text { alveolar bone } \\
\text { E-28K }^{[7]}\end{array}$ & $\begin{array}{l}\text { Porcine fetal } \\
\text { calvaria } \\
\text { SCAB 3b }\end{array}$ & $\begin{array}{l}\text { Calf skin } \\
\text { procollagen type I } \\
\text { pN-propeptide }^{[22]}\end{array}$ \\
\hline Hydroxyproline & 26 & 49 & 31 & 45 \\
Aspartate & 97 & 91 & 100 & 116 \\
Threonine & 51 & 51 & 39 & 45 \\
Serine & 36 & 20 & 38 & 26 \\
Glutamate & 157 & 149 & 153 & 141 \\
Proline & 123 & 137 & 103 & 141 \\
Glycine & 215 & 150 & 165 \\
Alanine & 55 & 44 & 81 & 19 \\
Valine & 73 & N.D. & 67 & 71 \\
Methionine & N.D. & 14 & $2 . D$. & N.D. \\
Cystine & 14 & 35 & 30 & 65 \\
Isoleucine & 33 & 32 & 55 & 32 \\
Leucine & 36 & 6 & 17 & 39 \\
Tyrosine & 5 & 6 & 20 & 6 \\
Phenylalanine & 10 & 6 & 19 & 6 \\
Histidine & 7 & 35 & 25 & 32 \\
Lysine & 33 & 34 & 50 & 32 \\
Arginine & 31 & & & \\
\hline
\end{tabular}

N.D.: Not detected 
content of acidic amino acids (25\%), glycine (21\%) and proline (12\%), but small amounts of cysteine, tyrosine, phenylalanine and histidine.

On the basis of the amino acid analysis, at least $150 \sim 200 \mu \mathrm{g}$ of G2-28K was purified from $90 \mathrm{~g}$ wet weight of alveolar bone.

\section{Discussion}

The presence of significant amounts of the $\alpha 1(\mathrm{I}) \mathrm{pN}$-propeptide of collagen has been demonstrated in fetal calf bone ${ }^{[1]}$ and neonatal human calvaria ${ }^{[2]}$. Furthermore, GoldBERG et al. ${ }^{[4]}$ have shown that two forms (SCAB $3 \mathrm{a}$ and $3 \mathrm{~b}$ ) of $28-\mathrm{kDa}$ collagenous proteins appear to be associated with hydroxyapatite crystals, since they are extracted only by EDTA. One form (SCAB 3b), like most of the other proteins in the EDTA extract (E-ext), bound to hydroxyapatite in the presence of protein denaturants in $10 \mathrm{mM}$ phosphate, whereas the second form (SCAB 3a) showed retarded mobility, but did not bind under these conditions. A third form (G2-28) is associated with the collagenous matrix, which was exposed following demineralization, and its behavior on hydroxyapatite chromatography was similar to SCAB 3a. MAENO et al. ${ }^{[7]}$ have also shown that the E-28K in E-ext of rabbit alveolar bone binds to hydroxyapatite crystals in the presence of $7.0 \mathrm{M}$ urea in $10 \mathrm{mM}$ phosphate, but a $28-\mathrm{kDa}$ collagenous protein in the demineralized rabbit bone matrix has not been well characterized so far.

In this study, we extracted a $28-\mathrm{kDa}$ protein in a subsequent extraction of demineralized bone matrix of alveolar bone from mandibles of young adult rabbits using $4.0 \mathrm{M} \mathrm{GuHCl}$, its molecular mass being same as that of the $\alpha 1$ (I)pN-propeptide from porcine fetal calvaria ${ }^{[4]}$, and its characteristics were investigated. Alveolar bone proteins from 3-month-old rabbits were extracted with $4.0 \mathrm{M} \mathrm{GuHCl}$, followed with $0.5 \mathrm{M}$ EDTA, and again with $4.0 \mathrm{M} \mathrm{GuHCl}$ (G2-ext), as described by Domenicucci et al. ${ }^{[8]}$, Goldberg et al. ${ }^{[4,9]}$, Ohmori et al. ${ }^{[10]}$, TAKagi et al. ${ }^{[11,12]}$ and MAENo et al. ${ }^{[7,13,14]}$ Proteins in the G2-ext were fractionated by Superdex 200 column chromatography in the presence of $7.0 \mathrm{M}$ urea. The eluate containing the $20 \sim 35-\mathrm{kDa}$ proteins was pooled, and the $28-\mathrm{kDa}$ protein was purified by two runs through Mono Q column in the presence of $7.0 \mathrm{M}$ urea.

The 28-kDa protein purified from the G2-ext (G2-28K) was stained strongly with silver after SDS-PAGE, similar to the $28-\mathrm{kDa}$ collagenous protein extracted from E-ext (E-28K) of rabbit alveolar bone described by MAENo et al. ${ }^{[7]}$ Also, the protein stained light blue with Stains-all, suggesting that the protein contains highly acidic amino acids and/or phosphate. Further analysis showed that G2-28K was degraded by bacterial collagenase to a 19-kDa fragment, indicating the presence of a collagenous region of approximately $9 \mathrm{kDa}$. The $19-\mathrm{kDa}$ fragment also stained light blue with Stains-all, indicating that the enzyme-resistant fragment of G2-28K is highly acidic and/or phosphorylated. The G2-28K was resistant to CNBr cleavage, indicating that the protein molecule does not contain methionine residues. Electrophoresis in the absence of urea and reduction produced a complex form $(\mathrm{Mr} ; \sim 85-\mathrm{kDa})$ of the G2-28K fraction.

In our studies, G2-28K did not bind to hydroxyapatite crystals under the same conditions as those described by Goldberg et al. ${ }^{[4]}$ and MAeno et al. ${ }^{[7]}$ Therefore, we presume that this protein has characteristics similar to those of SCAB 3a and G2-28 of fetal porcine bone ${ }^{[4]}$.

TERmine et al. ${ }^{[1]}$ showed the presence of glucosamine, galactosamine and sialic acid in the carbohydrate side chain of the $\alpha 1$ (I)pN-propeptide from fetal calf bone. Therefore, to determine the type of carbohydrate in G2-28K, the binding of lectins was analyzed by Western blotting using a lectin sensor kit capable of detecting the carbohydrate chain with high sensitivity. It was found that AAA, SSA, RCA 120 and DSA did not bind to the protein, indicating that the protein does not contain Fuc $\alpha 1$, Sia $\alpha 2-6 \mathrm{Gal}$, Gal and Gal $\beta 1-4 \mathrm{GlcNAc}$ in its carbohydrate chain.

The amino acid composition of G2-28K showed a characteristically high content of acidic amino acids, glycine and proline, but small amounts of cysteine, tyrosine, phenylalanine and 
histidine. The composition of G2-28K was similar to the $\alpha 1(\mathrm{I}) \mathrm{pN}$-propeptide from fetal calf skin $^{[22]}$ and fetal porcine bone ${ }^{[4]}$, and E-28K from adult rabbit alveolar bone ${ }^{[7]}$.

These results indicate that $\mathrm{G} 2-28 \mathrm{~K}$ is similar to the $\alpha 1(\mathrm{I}) \mathrm{pN}$-propeptide from fetal calf skin $^{[22]}$, fetal porcine bone ${ }^{[4]}$ and adult bovine bone ${ }^{[3]}$, and E-28K from adult rabbit alveolar bone ${ }^{[7]}$, but different from the other small collagenous apatite-binding proteins of porcine bone, SCABs 1 and $2^{[5,6]}$.

MAENO et al. ${ }^{[7]}$ demonstrated a significant amount (50 100 $\mu \mathrm{g}$ for $90 \mathrm{~g}$ of bone) of the $\alpha 1$ (I) $\mathrm{pN}$-propeptide in E-ext from alveolar bone of young adult rabbits, and also the production of this protein by rabbit alveolar bone-derived cells, suggesting that this protein is not incorporated non-specifically into bone along with serum-derived proteins.

In this study we showed that significant amounts $(150 \sim 200 \mu \mathrm{g}$ for $90 \mathrm{~g}$ of bone) of the $\alpha$ 1 (I)pN-propeptide were present in the G2-ext from alveolar bone of young adult rabbits, although the quantity was about double that in the E-ext from the same bone. The presence of the $\alpha 1(\mathrm{I}) \mathrm{pN}$-propeptide in alveolar bone may be important for regulation of hydroxyapatite crystal formation and/or dissolution during bone resorption for tooth movement with mechanical stress and bone remodeling.

\section{Acknowledgements}

This study was supported in part by a General Individual Research Grant (No. B93-086) and an Interdisciplinary General Joint Research Grant (No. DA93-013) from Nihon University Provisions Research Grants for 1993.

\section{References}

[1] Termine, J. D., Belcourt, A. B., Conn, K. M. and Kleinman, H. K.: Mineral and collagen-binding proteins of fetal calf bone, J. Biol. Chem., 256, 10403-10408, 1981

[2] Fisher, L. W., Robey, P. G., Tuross, N., Otsuka, A. S., Tepen, D. A., Esch, F. S., Shimasaki, S. and Termine, J. D.: The Mr 24,000 phosphoprotein from developing bone is the $\mathrm{NH}_{2}$-terminal propeptide of the $\alpha 1$ chain of type I collagen, J. Biol. Chem., 262, 13457-13466, 1987

[3] Kuboki, Y., Takita, H., Fujisawa, R., Yamaguchi, H., Yamada, H., Tazaki, M., Ohnuma, Y., Mizuno, M. and Tsuzaki, M.: Histidinoalanine-containing phosphoprotein in bone, Calcif. Tissue Int., 48, 196-203, 1991

[4] Goldberg, H. A., Maeno, M., Domenicucci, C., Zhang, Q. and Sodek, J.: Identification of small collagenous proteins with properties of procollagen $\alpha 1(\mathrm{I}) \mathrm{pN}$-propeptide in fetal porcine calvarial bone, Collagen Rel. Res., 8, 187-197, 1988

[5] Sodek, J., Goldberg, H. A., Domenicucci, C., Zhang, Q., Kwon, B., Maeno, M. and Kuwata, F.: Characterization of multiple forms of small collagenous apatite-binding proteins in bone, Connective Tissue Res., 20 , 233-240, 1989

[6] Kumata, F., Maeno, M., Yao, K-L., Domenicucci, C., Goldberg, H. A., Wasi, S., Aubin, J. E. and Sodek, J.: Characterization of a monoclonal antibody recognizing small collagenous proteins in fetal bone, Collagen Rel. Res., 7, 39-55, 1987

[7] Maeno, M., Suzuki, N., Ohmori, Y., Saito, R., Shiou, S., Sato, K., Otsuka, K. and Suzuki, K.: Characterization of a $28-\mathrm{kDa}$ collagenous protein extracted with EDTA from adult rabbit alveolar bone, J. Bone Mineral Metab., 10, 18-25, 1992

[8] Domenicucci, C., Goldberg, H., Hofmann, T., Isenman, D., Wasi, S. and Sodek, J.: Characterization of porcine osteonectin extracted from foetal calvariae, Biochem. J., 253, 139-151, 1988

[9] Goldberg, H. A., Domenicucci, C., Pringle, G. A. and Sodek, J.: Mineral-binding proteoglycans of fetal porcine calvarial bone, J. Biol. Chem., 263, 12092-12101, 1988

[10] Ohmori, Y., Suzukı, N., Maeno, M., Endo, T., Yajima, M., Inoue, T., Yamaguchi, T. and Otsuka, K.: Comparison of protein profiles on SDS-PAGE between EDTA and guanidine- $\mathrm{HCl}$ extracts from rabbit alveolar bone, Nihon Univ. Dent. J., 63, 86-92, 1989 (in Japanese)

[11] Takagi, M., Maeno, M., Kagami, A., Takahashi, Y. and Otsuka, K.: Biochemical and immunocytochemical characterization of mineral binding proteoglycans in rat bone, J. Histochem. Cytochem., 39, 41-50, 1991

[12] Takagi, M., Maeno, M., Takahashi, Y. and Otsuka, K.: Biochemical and immuno- and lectin-histochemical studies of solubility and retention of bone matrix proteins during EDTA demineralization, Histochem. J., 24, 78-85, 1992

[13] Maeno, M., Taguchi, M., Suzuki, N., Ogoshi, T., Naganuma, K., Tamura, Y., Nakano, K., Komori, F., 
Otsuka, K. and Suzuki, K.: Characterization of mineral-binding 40-kDa glycoprotein extracted from young adult rabbit alveolar bone, J. Nihon Univ. Sch. Dent., 34, 77-88, 1992

[14] Maeno, M., Taguchi, M., Kosuge, K., Otsuka, K. and TaKagi, M.: Nature and distribution of mineralbinding, keratan sulfate-containing glycoconjugates in rat and rabbit bone, J. Histochem. Cytochem., 40 , 1779-1788, 1992

[15] Laemmli, U. K.: Cleavage of structural proteins during the assembly of the head of bacteriophage T4, Nature, 227, 680-685, 1970

[16] Merril, C. R., Goldman, D. and Van Keuren, M. L.: Simplified silver protein detection and image enhancement methods in polyacrylamide gels, Electrophoresis, 3, 17-23, 1982

[17] Campbell, K. P., Maclennan, D. H. and Jorgensen, A. O.: Staining of the $\mathrm{Ca}^{2+}$-binding proteins, calsequestrin, calmodulin, troponin C, and S-100, with the cationic carbocyanine dye "Stains-all", J. Biol. Chem., 258, 11267-11273, 1983

[18] Yamashita, K., Kochibe, N., Ohkura, T., Ueda, I. and Kobata, A.: Fractionation of L-fucose-containing oligosaccharides on immobilized Aleuria aurantia lectin, J. Biol. Chem., 260, 4688-4693, 1985

[19] Shibuya, N., Tazaki, K., Song, Z., Tarr, G.E., Goldstern, I. J. and Peumans, W. J.: A comparative study of lectins from three elderberry (Sambucus) species, J. Biochem., 106, 1098-1103, 1989

[20] Baenziger, J. U. and Fiete, D.: Structural determinants of Ricinus communis agglutinin and toxin specificity for oligosaccharides, J. Biol. Chem., 254, 9795-9799, 1979

[21] Yamashita, K., Totani, K., Ohkura, T., Takasaki, S., Goldstein, I. J. and Kobata, A.: Carbohydrate binding properties of complex-type oligosaccharides on immobilized Datura stramonium lectin, J. Biol. Chem., 262, 1602-1607, 1987

[22] Horlein, D., Fietzek, P. P., Wachter, E., Lapiere, C. M. and Kuhn, K.: Amino acid sequence of the aminoterminal segment of dermatosparactic calf-skin procollagen type I, Eur. J. Biochem., 99, 31-38, 1979 